\title{
- RATOWNIK MEDYCZNY, PIELEGGNIARKA SYSTEMU BIEGŁYM SĄDOWYM Z ZAKRESU RATOWNICTWA MEDYCZNEGO
}

\section{A PARAMEDIC AND A SYSTEM NURSE AS EXPERT WITNESSES IN THE FIELD OF EMERGENCY MEDICAL SERVICES}

\author{
Dariusz Zawadzki ${ }^{1, a}$, Anna Rej-Kietla ${ }^{2, b}$ \\ ${ }^{1}$ Wojewódzka Stacja Ratownictwa Medycznego w Łodzi - Rejon Zgierz \\ ${ }^{2}$ Wydział Nauk o Zdrowiu Państwowej Medycznej Wyższej Szkoły Zawodowej w Opolu \\ ${ }^{\text {a }}$ https://orcid.org/0000-0003-4560-0440 \\ ${ }^{\mathrm{b}}$ https://orcid.org/0000-0002-7031-000X
}

DOI: https://doi.org/10.20883/pielpol.2019.44

\begin{abstract}
STRESZCZENIE
Życie i zdrowie to dobra chronione prawem. Ze względu na coraz większość świadomość społeczeństwa rośnie ryzyko składania do sądu pozwów przez osoby pokrzywdzone czy też doniesień do prokuratury o możliwości popełnienia przestępstwa przez personel medyczny. Biegły sądowy z zakresu różnych specjalności medycyny przyjmuje de facto rolę sądu, ponieważ opinia jest decydująca i wiążąca w prowadzonym postępowaniu prokuratorsko-sądowym. W przypadku wątpliwości można wystąpić o opinię do innego biegłego lub o opinię uzupełniającą.
\end{abstract}

SŁOWA KLUCZOWE: ratownik medyczny, pielęgniarka systemu, biegły sądowy, błąd medyczny, nieprawidłowe postępowanie.

\section{Wprowadzenie}

Biegły sądowy jest organem pomocniczym w sprawach wymagających specjalistycznej wiedzy. Biegłym może być osoba, która posiada teoretyczne i praktyczne wiadomości specjalne z danej gałęzi nauki. Sporządzona opinia przez biegłego obok kluczowych osób - sędziów, stron i ich pełnomocników, stanowi pełnoprawny materiał dowodowy przed sądami, ale również innymi władzami i organami wymiaru sprawiedliwości. Opinia ma na celu ułatwienie sądowi zrozumienie dziedziny wymagającej wiadomości specjalnych. Biegły jest pomocnikiem sądu poprzez reprezentację własnego stanowiska w sprawie, w której rozstrzyga sąd. Czas trwania postępowania sądowego uzależniony jest ze względu na oczekiwanie opinii biegłego. Następnym dość bardzo ważnym aspektem jest jakoś wydanej opinii, która powinna być jasna, rzetelna, pełna i wolna od wad [1].

Rola biegłego sądowego sięga II wieku p.n.e. w Egipcie, gdzie powoływano jednego lub dwóch lekarzy do oględzin osób pokrzywdzonych. Funkcja znana

\begin{abstract}
Life and health are goods protected by law. Due to the growing majority of public awareness, the risk of filing lawsuits by persons injured to court, or reports to the prosecutor's office about the possibility of a crime by medical personnel, is increasing. The expert witness in the field of various medical specialties de facto takes the role of court, because the opinion is decisive and binding in the prosecution-court proceedings. In case of doubts you can ask for an opinion of another expert or for a supplementary opinion.
\end{abstract}

KEYWORDS: paramedic, system nurse, expert witness, medical error, abnormal treatment.

była również w starożytnym Rzymie od czasów cesarza Justyniana. Na przełomie XV i XVI wieku w Polsce funkcję biegłego pełnili tak zwani fizycy miejscy, zaś wprowadzenie "medyka sądowego" nastąpiło w XVIII wieku, kiedy w 1750 roku komisja ustawodawcza powołana przez króla Stanisława Augusta wypowiedziała się w sprawie „znawców do badań sądowo-lekarskich” [2]. Na terenie zaborów pruskiego i austriackiego biegłych nazywano „znawcami”, w zaborze rosyjskim zaś wymieniano jako „czynności sądowo-lekarskie”. Dopiero po odzyskaniu przez Polskę niepodległości w 1918 roku wyżej wymienione nazwy zastąpiono pojęciem „biegłego sądowego" [3].

Aktualnie w polskim prawodawstwie jednym i głównym rozporządzeniem dotyczącym biegłych sądowych jest Rozporządzenie Ministra Sprawiedliwości z dnia 24 stycznia 2005 r. w sprawie biegłych sądowych. Sąd w sytuacjach wymagających wiedzy specjalistycznej powołuje biegłego lub biegłych, jeśli ich opinia jest niezbędna do rozstrzygnięcia sprawy. Wynika to z art. 193 
§ 1 Kodeksu Postępowania Karnego (Jeżeli stwierdzenie okoliczności mających istotne znaczenie dla rozstrzygnięcia sprawy wymaga wiadomości specjalnych, zasięga się opinii biegłego albo biegłych).

\section{Kim jest biegły sądowy (pot. biegły)?}

Jest to osoba powołana przez sąd lub na wniosek stron do wydawania opinii w zakresie specjalistycznym w danej dziedzinie, nie tylko medycynie. Biegły ma posiadać tzw. wiadomości specjalne, których katalog nie został określony i interpretacja tego pojęcia jest dowolna. Według orzeczenia Sądu Najwyższego wiadomości specjalne to takie, które wykraczają poza dostępne dla dorosłego człowieka o odpowiednim doświadczeniu życiowym, wykształceniu i zasobie wiedzy ogólnej [4]. Zgodnie z obowiązującą literą prawa, jeśli postępowanie wymaga posiadania wiadomości specjalnych, organ procesy powinien zasięgnąć opinii biegłego lub placówki opiniodawczej (np. Zakład Medycyny Sądowej) [5]. Według innych autorów wiadomości specjalne to takie, które posiadają tylko specjaliści medycyny sądowej. Opinia powinna być kompetentna, bezstronna, niezależna [6, 7]. Wśród biegłych można wyróżnić: stałych biegłych sądowych, osoby powoływane ad hoc do udziału w poszczególnych sprawach w charakterze biegłych, a także instytucje naukowe i specjalistyczne (art. 193 § 2 Kodeksu Postępowania Karnego) [8].

Biegłych można podzielić na biegłych z listy, opiniujących w sprawach karnych i cywilnych oraz biegłych ad hoc, opiniujących we wszystkich sprawach z wyjątkiem spraw administracyjnych.

\section{Opinia biegłego jako dowód w postępowaniu}

Ważnym elementem postępowania prokuratorsko-sądowego jest efektywne wykorzystanie wyników opinii biegłego lub zespołu biegłych, zarówno w postępowaniu cywilnym, jak i karnym. Opinia biegłego to pogląd osoby niezainteresowanej rozstrzygnięciem sprawy. Jego rola to przedstawienie profesjonalnych wiadomości dotyczących prawidłowego postępowania medycznego w celu ustalenia okoliczności faktycznych dla danej sprawy. Wynika to z art. 278 § 1 k.p.c. (W wypadkach wymagających wiadomości specjalnych sąd po wysłuchaniu wniosków stron co do liczby biegłych i ich wyboru może wezwać jednego lub kilku biegłych w celu zasięgnięcia ich opinii). Biegły ma obowiązek odpowiedzieć konkretnie na zadane pytania przez prokuratora lub sąd, które powinny być postawione precyzyjnie i spójnie w tezie dowodowej. Biegły powinien być powołany zawsze wtedy, kiedy do rozstrzygnięcia sprawy niezbędna jest wiedza specjalistyczna z danego zakresu. Według Sądu Najwyższego opinia biegłego podlega ocenie wiarygodności i mocy dowodów na podsta- wie art. 233 § 1 k.p.c. (Sąd ocenia wiarygodność i moc dowodów według własnego przekonania, na podstawie wszechstronnego rozważenia zebranego materiału). W przypadku kontrowersyjnej opinii sąd może złożyć wniosek o wydanie opinii uzupełniającej, wezwać biegłego na rozprawę, ale również wydać żądanie dowodu z opinii innego biegłego lub zespołu biegłych. Takie postępowanie wynika z art. 286 k.p.c. (Sąd może zażądać ustnego wyjaśnienia opinii złożonej na piśmie, może też $w$ razie potrzeby zażądać dodatkowej opinii od tych samych lub innych biegłych) $[9,10,11,12]$.

Z wielu judykatów dotyczących oceny dowodu z opinii biegłego wyróżniono kilka kryteriów dotyczących procesu karnego.

- „Aktualna wiedza” - biegły wydając opinię zobowiązany jest do posługiwania się aktualną wiedzą medyczną. Wynika to z wyroku SN z dnia 6 listopada 2000 r. oraz wyroku z dnia 17 grudnia 2008 r., w których zaleca się merytoryczne zweryfikowanie opinii, uwzględniając aktualny stan wiedzy w danej dziedzinie. Według Waltosia i Hetmańskiego ocena dowodów powinna być zgodna z wiarygodnymi i najnowszymi wynikami badań naukowych i wykorzystać osiągnięcia naukowe [13, 14, 15]. Z wyrokami sądów się nie dyskutuje, ale nie można się zgodzić do końca, że opinia ma być wydana na bazie aktualnej wiedzy medycznej. Jak się ma taka sytuacja, kiedy opinia zostaje wydana dwa lata po zaistnieniu zdarzenia? Towarzystwo naukowe danej dziedziny mogło zmienić postępowanie w danym przypadku. Opinia wydana w roku, kiedy miało miejsce zdarzenia będzie różniła się od opinii wydanej dwa lata później.

- "Ocena wiedzy, kompetencji i rzetelności” według wyroku SN z dnia 12 listopada 2002 r. wynika, że kryteria oceny wyników pracy biegłego opierają się na weryfikacji wiedzy, kompetencji i rzetelności biegłego. Biegły powinien być specjalistą w dziedzinie, która dotyczy bezpośrednio prowadzonego postępowania karnego. Przyszłego biegłego należy zweryfikować pod kątem posiadanych kwalifikacji zawodowych, etyki oraz doświadczenia w dziedzinie reprezentowanej przez biegłego. Do naruszenia tej przesłanki dochodzi w chwili, gdy od samego początku osoba powołana w charakterze biegłego nie miała wiedzy specjalistycznej (ekspertalnej) i nie spełniała kryteriów powołania w charakterze biegłego (art. 193 § 1 k.p.c.). Problem zdefiniowania instytucji naukowej lub specjalistycznej zgodnie z art. 193 § 2 k.p.k. nie znajduje rozwiązania w aktualnej judykaturze. 
Wyrok SA w Krakowie z dnia 3 lipca 2002 r. za instytucję naukową lub specjalistyczną przyjął „instytucje naukowe lub specjalistyczne (...), które są jednostkami Polskiej Akademii Nauk, bądź szkół wyższych lub jednostki badawczo rozwojowe (...) [16, 17, 18].

- Jasność opinii” - opinie powinna być sporządzona w taki sposób, aby nie budziła niewyjaśnionych sprzeczności i wątpliwości. Na podstawie dotychczasowego orzecznictwa opinia sporządzona przez biegłego musi być „pełna, jasna, nie może zachodzić niewyjaśniona sprzeczność pomiędzy jedną a drugą opinią sporządzoną przez innego biegłego w toku postępowania sądowego". W przypadku wystąpienia wad opinii (niepełność, niejasność, sprzeczność wewnętrzna lub między opiniami), art. 201 k.p.c. pozwala na usunięcie wad opinii $[19,20]$.

\section{Ratownik medyczny, pielęgniarka systemu biegłym sądowym?}

Dotychczas w postępowaniu procesowym z zakresu ratownictwa medycznego, bez względu na rodzaj sprawy czy osoby, której dotyczyła, biegłym w zakresie medycyny był zawsze lekarz. Tak naprawdę dzieje się to do dnia dzisiejszego. W sprawach dotyczących nieprawidłowego postępowania przez ratowników medycznych czy pielęgniarki systemu, głównie w warunkach przedszpitalnych, biegłym jest zazwyczaj lekarz medycyny ratunkowej lub anestezjologii i intensywnej terapii oraz specjalista medycyny sądowej. Brak przesłanek prawnych co do wyznaczania jako biegłego tylko lekarza. Ze względu na fakt, że opinia wydawana jest zazwyczaj przez zespół biegłych, wydaje się być zasadnym, aby jedną z nich była osoba, która zawodowo związana jest $z$ ratownictwem medycznym. Ostatecznie opinię zatwierdza specjalista medycyny sądowej. Uzasadnieniem dla tej decyzji jest fakt, że procedury postępowania, wytyczne Towarzystw Naukowych nieco różnią się od siebie ze względu na poziom udzielanej pomocy. Według autorów najlepsze miejsca dla ratownika medycznego, pielęgniarki systemu jako biegłego sądowego jest w opiniowaniu spraw w przypadku pierwszej i kwalifikowanej pierwszej pomocy. W innych sprawach z zakresu ratownictwa medycznego jako wydanie opinii wspólnie z innymi specjalistami - lekarzami z tej dziedziny.

Procedura dotycząca powoływania biegłego sądowego wynika z rozporządzenia Ministra Sprawiedliwości z dnia 24 stycznia 2005 roku, w sprawie biegłych sądowych.

Wydawać opinie sądowo-lekarskie dotyczące uszczerbku na zdrowiu, orzekać o stanie zdrowia może tylko lekarz. Wynika to z art. 2.1 ustawy zawodach lekarza i lekarza dentysty [21].
Należy jednak pamiętać, że opiniowanie spraw jest pracą specyficzną i bardzo trudną. Oprócz posiadanej wiedzy i umiejętności opiniowania, biegły ponosi pełną odpowiedzialność za wydaną opinię, co skutkuje obciążeniem prawnym biegłego (art. 233 § 4 kodeksu karnego - kto, jako biegły, rzeczoznawca lub tłumacz, przedstawia fałszywą opinię lub tłumaczenie mające służyć za dowód w postępowaniu określonym w § 1, podlega karze pozbawienia wolności do lat 3).

\section{Podsumowanie}

1. W procesie medycznym niezastąpiona jest opinia specjalisty z danej dziedziny medycyny.

2. Rola biegłego jest bardzo odpowiedzialnym zadaniem wydania opinii dla potrzeb sądu lub prokuratury i powinna być sporządzona w sposób rzetelny, profesjonalny, zgodny z aktualną wiedzą medyczną, niebudzący wątpliwości i zastrzeżeń.

3. Biegłym sądowym może być każda osoba legitymująca się odpowiednim wykształceniem, wiedzą, doświadczeniem zawodowym oraz wiadomościami specjalnymi.

4. Aby pełnić funkcję biegłego należy posiadać nadprzeciętne predyspozycje oraz znajomość przepisów prawnych.

5. Według autora pracy „Opinia biegłego lekarza jako dowód w procesie medycznym-wybrane aspekty" można odnaleźć opinie biegłych lekarzy, które są wynikiem solidarności zawodowej i środowisko to nie jest skłonne do samokrytyki.

6. Brak przeciwwskazań do występowania ratownika medycznego, pielęgniarki systemu w roli biegłego sądowego ad hoc jak również z listy biegłych.

7. Biegli sądowi wspierają wymiar sprawiedliwości posiłkując się swoją wiedzą oraz doświadczeniem zawodowym.

\section{Piśmiennictwo}

1. Kubiak R. Prawo medyczne. Warszawa: 2014: 1.

2. Wróblewski K. Arch. Med. Sąd. i Krym: 1993, 3: 326-328.

3. Bilski D. Zdr., Publ.: 2001, 4: 278-281.

4. Rybarczyk M. Biegły w postępowaniu cywilnym: opinia, odpowiedzialność, wynagrodzenie: C.H. Beck, Warszawa: 2001.

5. Nowak Z. Gazeta Wyborcza: 2003, 172, 1: 14.

6. Scurr J.H. Medico-Legal J.: 2000, 2: 62-64.

7. Marcinkowski J. Problemy higieny i epidemiologii u progu XXI wieku. Materiały pokonferencyjne Ogólnopolskiej Konferencji Naukowej: Poznań-Kiekrz. 6-8 V 2001 r. Cz. 1-3. Pol. Tow. Higieniczne: Warszawa: 2001, 196: 221.

8. Wiśniewska-Śliwińska H, Marcinkowski JT. Biegły sądowy - tryb powoływania, wymagania, obowiązki, Orzecznictwo Lekarskie 2011 r., 8(1): 33-39.

9. Gajda-Roszczynialska K, Błaszczak J, Markiewicz K. (red), Pojęcie dowodu z opinii biegłego: op. cit.: 619. 
10. Ustawa z dnia 17 listopada 1964 r. - Kodeks posteppowania cywilnego (tekst jedn. Dz. U. z 2014 r., z poz. 101 ze zm.).

11. Postanowienie SN z dnia 7 listopada 2000 r., sygn. akt I CKN 1170/98, OSNC 2001, nr 4, poz. 64.

12. Wyrok SA w Białymstoku z dnia 3 sierpnia 2012 r., sygn. akt I ACa 217/12, Legalis nr 733687.

13. Wyrok SN z dnia 6 listopada 2000 r., sygn. akt IV KKN 477/99. Orzecznictwo Prokuratury i Prawa, 2001, nr 4, poz. 9.

14. Wyrok SN z dnia 17 grudnia 2008 r., sygn. akt II KK 140/08, LEX nr 486186.

15. Waltoś S. Hetmański P.: Proces karny, 2016: 253.

16. Sygn. akt V KKN 330/01, LEX nr 56854.

17. Wyrok SA w Krakowie z dnia 26 października 2004 r., sygn. akt II Aka 207/04, KZS 2004, nr 12, poz. 28.

18. Sygn. akt II Aka 3/02. KZS 2002, nr 7-8, poz. 53.

19. Wyrok SN z dnia 6 listopada 2002 r., sygn. akt IV KKN 308/99, LEX nr 56851.

20. Hofmański P, Sadzik E, Zgryzek K. Kodeks postępowania karnego, t. I: Komentarz do artykułów 1-296, wyd. IV: Warszawa: C.H. Beck 2011: 1140.
21. Ustawa o zawodach lekarza i lekarza dentysty z dnia 5 grudnia 1996 r., Rozdział I, Przepisy ogólne.

Artykuł przyjęty do redakcji: 01.10.2018.

Artykuł przyjęty do publikacji: 09.07.2019.

Źródło finansowania: Praca nie jest finansowana z żadnego źródła. Konflikt interesów: Autorzy deklarują brak konfliktu interesów.

\section{Adres do korespondencji:}

Dariusz Zawadzki

Wojewódzka Stacja Ratownictwa Medycznego w Łodzi - Rejon Zgierz ul. Parzęczewska 35

95-100 Zgierz

e-mail:dariusz.zawadzki@wsrm.lodz.pl 